\begin{tabular}{|l|l|} 
Jurnal Bimbingan dan Konseling Ar-Rahman \\
Volume 4, Nomor 2, Tahun 2018 \\
Tersedia Online: http://ojs.uniska.ac.id/index.php/BKA \\
e-ISSN 2477-6300
\end{tabular}

\title{
PENGEMBANGAN PERANGKAT PEMBELAJARAN BIMBINGAN DAN KONSELING UNTUK MENGOPTIMALKAN PERKEMBANGAN SOSIAL ANAK KELAS I SD
}

\author{
Vinda Chairunnisa ${ }^{1}$, M. Fauzi Hasibuan ${ }^{2}$ \\ ${ }^{1}$ Universitas Muslim Nusantara Medan \\ ${ }^{2}$ Universitas Muhammadiyah Sumatera Utara \\ E-mail:
}

\begin{abstract}
ABSTRAK
Penelitian ini bertujuan untuk merumuskan kelayakan perangkat pembelajaran bimbingan dan konseling untuk mengoptimalkan perkembangan sosial peserta didik dan juga keterpakaian oleh guru kelas (guru BK/konselor) di SD. Metode penelitian ini dengan menggunakan model ADDIE. Subjekuji cobapenelitianterdiri darilimaorangahliuntukmengujikelayakan,dantiga orang guru kelas (guru BK/konselor). Instrument yang digunakan ialah sklala likert, kuisioner dan Focus Group Discussion (FGD). Data hasilpenelitiandianalisis menggunakan analisis deskriptifdan analisis statistik nonparametrik. Temuan penelitian memperlihatkan bahwa perangkat pembelajaran BK ini dapat dimanfaatkan oleh guru kelas untuk membantu guru dalam mengoptimalkan perkembangan sosial peserta didik.
\end{abstract}

Kata Kunci: Perkembangan Sosial, Perangkat Pembelajaran

\begin{abstract}
This research aims to formulate guidance and counseling learning toolto optimizing social development of student and describe the level of appalicability used by theacher or counselor. The method used was ADDIE model development. the properness tes was done by five experts and the practicality tes was done by three teacher or counselor. the instrument used were likert scale, questionnaire and Focus Group Discussion (FGD). The data statistic gathered in this research was analyzed by using descriptive statistic analysis and nonparametric statistic analysis. Based on thes results, in general, it was conclueded that the guidance and counseling learning tool's developed was appropriate and could be used to help the teacher to optimizing social development student.
\end{abstract}

Keywords: Social Development, Learning Tools

Dipublikasikan Oleh :

UPT Publikasi dan Pengelolaan Jurnal

Universitas Islam Kalimantan Muhammad Arsyad Al-Banjari Banjarmasin 


\section{PENDAHULUAN}

Masa usia Sekolah Dasar (selanjutnya disingkat dengan SD) adalah masa rentang usia anak antara 6-12 tahun yang masa kanak-kanaknya telah berakhir. Pada usia ini anak mengalami berbagai perkembangan dengan pesat, baik itu fisik, motorik, kognitif, intelektual, sosial, dan emosional. Yusuf (2014:101) menjelaskan bahwa, "Aspek-aspek perkembangan meliputi fisik, kecerdasan, emosi, bahasa, sosial kepribadian, moral, dan kesadaran beragama".Selain itu, perkembangan anak sudah optimal untuk memasuki lingkungan masyarakat di luar keluarganya, karena anak membutuhkan lingkungan sosial baru seperti sekolah, yaitu lembaga pendidikan yang bertujuan agar anak dapat mengembangkan fungsi intelektual dan potensi yang dimilikinya, sehingga anak mampu membuka cakrawalanya lebih luas.

Ahmadi dan Sholeh (2005) menerangkan bahwa anak memerlukan satu lingkungan sosial baru yang lebih luas, berupa sekolah untuk mengembangkan potensi yang dimilikinya, karena pada usia SD perkembangan anak sangat pesat sedangkan lingkungan keluarga tidak mampu memberikan fasilitas untuk mengembangkan fungsi intelektual dalam mengikuti kemajuan zaman modern.Peraturan Menteri Pendidikan dan Kebudayaan Nomor 57 Tahun 2014 tentang Kurikulum 2013 SD/MI menjelaskan bahwa pelaksanaan Kurikulum 2013 pada SD/MI dilakukan melalui pembelajaran dengan pendekatan tematik terpadu dari kelas I sampai Kelas VI. Kompetensi Dasar (KD) yang harus dimiliki oleh peserta didik ada empat, yaitu sikap spiritual (KI-1), sikap sosial (KI-2), pengetahuan (KI-3), dan keterampilan (KI-4). Pembelajaran tematik terpadu menyajikan konsepkonsep dari berbagai mata pelajaran yang terdapat pada KD KI-3 dan KI-4 dalam suatu proses pembelajaran. Sedangkan KI-1 dan KI-2 diharapkan dapat dikembangkan melalui implementasi KD KI-3 dan KI-4.

Pengembangan sikap sosial (KI-2) merupakan salah satu dari enam bidang pengembangan dalam Bimbingan dan Konseling (selanjutnya disingkat dengan BK), yang mana bidang pengembangan tersebut ialah: bidang pengembangan pribadi, sosial, belajar, karir, keluarga, dan keagamaan. Pada Lampiran Peraturan Menteri Pendidikan dan Kebudayaan Republik Indonesia Nomor 111 Tahun 2014 tentang Bimbingan dan Konseling pada Pendidikan Dasar dan Pendidikan Menengah dinyatakan bahwa pada satu sekolah dasar atau gugus/sejumlah $\mathrm{SD}$ diangkat guru $\mathrm{BK} /$ konselor untuk menyelenggarakan layanan BK. Sedangkan posisi struktural untuk guru BK/konselor belum ditemukan di SD, namun demikian anak usia SD membutuhkan layanan sesuai dengan tingkat perkembangannya.

Peraturan Menteri Pendidikan Nasional Nomor 35 Tahun 2010 tentang Petunjuk Teknis Pelaksanaan Jabatan Fungsional Guru dan Angka Kreditnya menyatakan bahwa untuk guru kelas, di samping wajib melaksanakan proses pembelajaran juga wajib melaksanakan program BK terhadap peserta didik di kelas yang menjadi tanggung jawabnya. Jadi ketika $\mathrm{SD}$ tidak/belum memiliki guru BK/konselor maka layanan BK dilaksanakan oleh guru kelas sehingga materi-materi BK dapat dipadukan dengan materi ajar melalui pembelajaran tematik. Oleh sebab itu perlu adanya perangkat pembelajaran BK sebagai panduan bagi guru kelas dalam memberikan layanan $\mathrm{BK}$ kepada peserta didik.

Tim Penyusun Panduan Operasional Penyelenggaraan BK SD (2016) menjelaskan bahwa terdapat sepuluh aspek perkembangan dalam Standar Kompetensi Kemandirian Peserta Didik (SKKPD) terkait dengan tugas perkembangan peserta didik diantaranya: (1) ladasan hidup religious,( 2) landasan perilaku etis, (3) kematangan emosi, (4) kematangan intelektual, (5) kesadaran tanggung jawab sosial, (6) kesadaran gender, (7) pengembangan pribadi, (8) perilaku kewirausahaan/ kemandirian perilaku ekonomis, (9) wawasan dan kesiapan karir, (10) kematangan hubungan dengan teman sebaya. Aspekaspek perkembangan dalam SKKPD akan menjadi rujukan untuk rumusan kompetensi oleh guru kelas (guru BK/konselor) dalam mempersiapkan pelaksanaan layanan BK di SD.

Perangkat pembelajaran BK diharapkan dapat membantu guru kelas agar layanan BK terlaksana secara efektif dan mencapai tujuan layanan. Peserta didik juga diharapkan mampu menjadi pribadi yang mandiri dan dapat mengembangkan potensinya secara optimal. Seperti yang dipaparkan Prayitno (2009:26) "Pelaksanaan konseling tertuju kepada kondisi pribadi yang mandiri, sukses, dan berkehidupan efektif dalam kesehariannya".

Berdasarkan fenomena yang dialami oleh siswa menunjukkan adanya masalah dalam tingkat perkembangan sosial siswa dari waktu ke waktu. Penelitian yang dilakukan oleh Halimah (2010) menunjukkan bahwa $77 \%$ siswa memiliki tingkat perkembangan sosial berada pada tahap yang sedang. Selanjutnya penelitian yang dilakukan Siagian (2010) ditemukan bahwa hanya $40 \%$ siswa memiliki tingkat perkembangan sosial pada tahap tinggi sedangkan yang lain perlu ditingkatkan lagi. Kemudian penelitian yang dilakukan Sodikin (2011) menunjukkan 66,7\% kemampuan berinteraksi anak berada pada kategori sedang. Di samping itu, berdasarkan penelitian yang dilakukan oleh Risanti (2013) 55,5\% tingkat 
perkembangan sosial anak masih berada pada kategori rendah. Berdasarkan fenomena tersebut maka perlu adanya perangkat pembelajaran untuk mengoptimalkan perkembangan sosial anak yang sesuai dengan usia perkembangannya.

Fakta di sekolah menunjukkan bahwa guru kelas tidak memiliki panduan khusus dalam pemberian layanan BK. Guru kelas berpendapat bahwa pemberian layanan BK sudah terlaksana secara tidak langsung dalam pembelajaran tematik terpadu. Guru kelas mengakui perlu adanya kontinuitas dalam memberikan pelayanan BK terkait dengan kondisi peserta didik di lapangan, terutama dalam tanggung jawab dan sikap sosialnya. Namun terkadang guru kelas sudah terdogma oleh materi yang sudah ditetapkan pada tematik terpadu, yang padahal kondisi anak di lapangan masih membutuhkan topik layanan BK secara kontinuitas. Selain itu, Kepala Sekolah juga mengharapkan adanya perangkat pembelajaran sebagai salah satu sarana untuk mengoptimalkan perkembangan sosial peserta didik.

Perkembangan sosial anak usia SD memiliki karakteristik khusus dalam berperilaku yang direalisasikan dalam bentuk tindakan-tindakan tertentu. Perkembangan sosial anak sangat dipengaruhi oleh proses perlakuan atau bimbingan orang tua serta lembaga pendidikan terhadap anak dalam berbagai aspek kehidupan sosial, atau normanorma kehidupan bermasyarakat. Keluarga dan lembaga pendidikan mendorong dan memberikan contoh kepada anak bagaimana menerapkan normanorma yang berlaku dalam kehidupan sehari-hari.

Havighurst (dalam Hurlock, 1978) menjelaskan bahwa sebelum masuk SD, anak telah Mengembangkan keterampilan berpikir bertindak dan pengaruh sosial yang lebih kompleks, namun pada dasarnya anak masih berpusat pada diri sendiri (egosentris) dan dunia mereka adalah rumah keluarga, dan taman kanak- kanaknya. Setelah masuk SD, anak mulai percaya diri namun juga masih ada rasa rendah diri, meskipun bergitu, anak mulai mencoba membuktikan bahwa mereka "dewasa". Mereka merasa "saya dapat mengerjakan sendiri tugas itu", karenanya tahap ini disebut tahap "I can do it my self". Jadi mereka sudah mampu untuk diberikan suatu tugas untuk dirinya sendiri dan bertanggung jawab atas tugas pribadinya.

Beranjak dari fenomena dan masalah mengenai sosial peserta didik kelas I di SD mendorong peneliti untuk melihat bagaimana caranya untuk mengoptimalkan sosial peserta didik kelas I di SD. Dalam rangka mengoptimalkan pengembangan sosial peserta didik kelas I, guru kelas yang secara langsung juga berperan sebagai guru BK di SD belum memiliki media yang dapat digunakan untuk melakukan pelayanan BK. Oleh sebab itu, peneliti tertarik untuk

\section{Dipublikasikan Oleh :}

UPT Publikasi dan Pengelolaan Jurnal

Universitas Islam Kalimantan Muhammad Arsyad Al-Banjari Banjarmasin mengembangkan media berupa perangkat pembelajaran BK untuk mengoptimalkan perkembangan sosial peserta didik kelas I di SD. Hal ini juga diperkuat dengan hasil wawancara yang dilakukan kepada guru kelas dibeberapa SD Kecamatan Sungayang bahwa guru kelas membutuhkan perangkat pembelajaran yang dapat membantu proses perkembangan sosial peserta didik kelas I di SD secara optimal. Selain itu, Kepala Sekolah juga berpendapat perlu adanya perangkat pembelajaran yang dapat menuntun anak untuk memiliki rasa tanggung jawab sosial.

Bedasarkan pemanfaatan perangkat pembelajaran BK untuk mengoptimalkan perkembangan sosial anak SD, diharapkan perkembangan sosial peserta didik kelas I dapat berkembang secara optimal sesuai dengan usia perkembangannya. Trianto (2011:201) menjelaskan bahwa perangkat pembelajaran adalah "Komponen prangkat yang digunakan untuk mengelola proses pembelajaran sehingga dapat mencapai kompetensi yang ingin dicapai secara maksimal."

Berangkat dari hal tersebut, maka peneliti ingin mengembangkan perangkat pembelajaran untuk mengoptimalkan perkembangan sosial anak kelas I SD. Peneliti sangat mengharapkan produk yang dikembangkan dalam penelitian ini dapat digunakan dalam praktik pelayanan konseling. Berdasarkan penjelasan di atas, maka penelitian ini dirancang untuk mencapai tujuan pengembangan sebagai berikut: (1) menghasilkan perangkat pembelajaran untuk mengoptimalkan perkembangan sosial anak kelas I SD yang layak secara isi, dan (2) mendeskripsikan tingkat keterpakaian perangkat pembelajaran untuk mengoptimalkan perkembangan sosial anak kelas I SD oleh guru bimbingan dan konseling atau konselor.

\section{METODE}

Penelitian ini merupakan penelitian pengembangan research and development $(R \& D)$. Prosedur pengembangan yang diterapkan dalam penelitian ini mengikuti langkah-langkah pengembangan menurut model ADDIE yang meliputi Analyze, Design, Development, Implementation, dan Evaluation (dalam Molenda, 2003). Kegiatan pengembangan produk yang dilakukan peneliti hanya sampai pada tahap uji kelompok kecil atau uji keterpakaian produk oleh guru kelas (guru BK/konselor). Subjek uji coba dalam penelitian ini terdiri daritenaga ahli yang terdiri dari lima orang untuk melakukan uji kelayakan terhadap produkdan tenaga praktisi yaitu guru kelas (guru BK/konselor) yang terdiri dari tiga orang untuk menilai uji keterpakaian dari produk yang telah dirancang.

Pengumpulan data dalam penelitian ini menggunakan skala likert, angket, dan melalui Focus 
Group Discussion (FGD). Data yang terkumpul selanjutnya diolah secara deskriptif untuk mengambarkan karakteristik distribusi skor masingmasing responden dengan menetapkan kategori dari hasil uji coba produk. Di samping itu, penelitian ini juga mengunakan statistik nonparametrik dengan memanfaatkan uji Koefesien Concordance Kendall's $W$.

\section{HASIL DAN PEMBAHASAN}

HASIL

Berdasarkan hasil penelitian, dapat diungkapkan bahwa melalui uji coba kelayakan pada tahap depelopment oleh ahli terhadap perangkat pembelajaran untuk mengoptimalkan perkembangan sosial anak kelas I SD menunjukan secara keseluruhan denganpersentase 81 pada kategori layak untuk dilaksanakan di SD setelah disempurnakan sesuai dengan masukan validator sehingga dihasilkan perangkat pembelajaran untuk mengoptimalkan perkembangan sosial anak kelas I SD sebagai hasil produk dan siap untuk dilaksanakan dan diujicoba keterpakaian di sekolah oleh guru kelas (guru BK/konselor).

Selanjutnya berdasarkan hasil uji Koefesien Concordance Kendall'sW, terhadap penilaian ahli diperoleh probabilitas sebesar 0,007. Dengan demikian, dapat dikatakan bahwa terdapat keselarasan/kesesuaian penilaian dari kelima ahli terhadap produk penelitian.

Pada tahap implementationoleh guru bimbingan dan konseling atau konselor, didapatkan hasil uji keterpakaian persentase 92 pada kategori sangat tinggi. Artinya bahwa penilaian yang diberikan oleh guru kelas (guru BK/konselor)mengenai perangkat pembelajaran yang disusun dapat diterapkan atau digunakan oleh guru kelas (guru BK/konselor) di sekolah. Kemudian melalui uji Koefesien Konkordansi Kendall's W,diperoleh probabilitas sebesar 0,024. Artinya terdapat keselarasan/kesesuaian penilaian dari ketiga guru bimbingan dan konseling atau konselor terhadap produk penelitian.

Kemudian melalui proses FGD pada tahap evaluation didapatkan hasil bahwasecara keseluruhan penilaian yang diberikan oleh peserta FGD terhadap modul berada pada kategori sangat baik dengan dengan persentase 92 dan juga panduan modul berada pada kategori sangat baik dengan persentase 89,8 . Artinya bahwa para peserta FGD memberikan penilaian yang positif terhadap perangkat pembelajaran untuk mengoptimalkan perkembangan sosial anak kelas I SD sebagai media dalam memberikan layanan bimbingan dan konseling dan siap untuk dipakai dalam pelayanan bimbingan dan konseling di sekolah.

\section{PEMBAHASAN}

Pengembangan produk pada penelitian ini menghasilkan prototype modul bimbingan dan konseling untuk mengoptimalkan perkembangan sosial peserta didik beserta panduan penggunaan perangkat pembelajaran untuk guru kelas (guru $\mathrm{BK} /$ konselor) dalam melakukan layanan konseling.

\section{Tingkat Kelayakan Perangkat Pembelajaran BK untuk Mengoptimalkan Perkembangan Sosial Anak Kelas I SD}

Dari hasil yang disajikan dalam tahap development diketahui bahwa perangkat pembelajaran yang disusun telah mencapai kriteria layak secara isi oleh para ahli. Penilaian terhadap aspek tampilan atau daya tarik dari perangkat pembelajaran yang disusun menarik. Artinya, tampilan dari perangkat pembelajaran yang dikembangkan tersebut dapat menarik minat siswa untuk membahas materi di dalamnya. Kemudian untuk aspek langkah-langkah pelaksanaan perangkat pembelajaran yang dikembangkan dapat dioperasionalkan oleh guru kelas (guru $\mathrm{BK} /$ konselor). Hal ini berarti bahwa guru kelas (guru BK/konselor) dapat memanfaatkan perangkat pembelajaran yang dikembangkan.

Selanjutnya materi perangkat pembelajaran yang dikembangkan mudah dipahami oleh guru kelas (guru BK/konselor). Setiap instruksi dan paparan informasi yang ditampilkan bersifat membantu dan bersahabat dengan pemakaiannya, termasuk kemudahan dalam merespon dan mengakses sesuai dengan keinginan. Penggunaan bahasa yang sederhana, mudah dimengerti, serta menggunakan istilah yang umum digunakan, merupakan salah satu bentuk user friendly.

Selain itu perangkat pembelajaran yang peneliti rancang memiliki karakteristik yang tidak jauh berbeda dengan modul yaitu memiliki tujuan yang jelas, tidak bergatung pada materi lain, dan bersahabat dengan pemakainya. Sesuai dengan pendapat Daryanto (2013) kaidah yang harus dimiliki modul ialah: (a) Self-instruction yaitu memiliki tujuan dan pembelajaran yang jelas, contohnya seperti menyediakan tugas dan evaluasi; (b) stand alone yaitu dapat dipahami secara mandiri oleh peserta didik tanpa bergantung pada bahan materi lain; (c) user friendly yaitu bersahabat/akrab dengan pemakaiannya, berupa bahasa yang sederhana dan mudah dipahami dan gambar-gambar yang menarik.

Penilaian yang diberikan oleh ahli terkait sembilan aspek, yaitu tampilan/daya tarik, langkah-langkah pelaksanaan perangkat pembelajaran, peranan guru kelas (guru 
BK/konselor), materi dan pemakaian bahasa tidak ada yang menunjukkan penilaian yang dibawah standar kelayakan. Hal ini semakin menguatkan bahwa perangkat pembelajaran untuk peserta mengoptimalkan perkembangan sosial peserta didik layak untuk dimanfaatkan oleh guru kelas (guru BK/konselor) dan dapat diinfusikan dalam pembelajaran tematik terpadu Kurikulum 2013.

Mengingat pentingnya mengoptimalkan perkembangan sosial anak sejak dini, ialah agar anak mampu melaksanakan tanggung jawab sosialnya sesuai dengan SKKPD yang tertera pada Panduan Pelayanan BK SD yaitu kesadaran tanggung jawab sosial. Hal ini mendukung anak untuk melakukan hubungan sosial di dalam kehidupan sehari-hari, baik itu di lingkungan keluarga, masyarakat, serta lingkungan sekolah, maka perlu dibantu melalui layanan oleh guru kelas (guru BK/konselor). Guru kelas (guru $\mathrm{BK} /$ konselor) harus mampu memberikan pemahaman dan pengetahuan kepada peserta didik tentang kesadaran tanggung jawab sosial, salah satunya dengan menggunakan perangkat pembelajaran untuk mengoptimalkan perkembangan sosial anak kelas I SD.

\section{Tingkat Keterpakaian Perangkat Pembelajaran BK untuk Mengoptimalkan Per-kembangan Sosial Anak Kelas I SD}

Pengimplementasian perangkat pembelajaran bk untuk mengoptimalkan perkembangan sosial anak kelas I SD yang disusun telah mencapai taraf keterpakaian yang memadai. Untuk aspek perencanaan dapat dilakukan oleh guru bimbingandankonseling atau konselor dengan baik. Segala alat yang dibutuhkan untuk penggunaan perangkat pembelajaran dapat disediakan oleh guru kelas (guru BK/konselor). Selanjutnya aspek pelaksanaan menunjukkan bahwa guru guru kelas (guru BK/konselor) dapat mengikuti langkahlangkah yang telah disusun. Selanjutnya aspek evaluasi yang digunakan sudah mampu melihat perolehan siswa setelah mengikuti layanan.

Materi pada perangkat pembelajaran BK yang telah disusun selanjutnya diterapkan oleh guru kelas (guru BK/konselor). Berdasarkan aspek pemakaian bahasa pada materi perangkat pembelajaran telah disesuaikan dengan kemampuan peserta didik kelas I SD, agar peserta didik mampu memahami materi dan mengikuti berbagai langkah pelaksanaan perangkat pembelajaran.Berhubung pengguna perangkat pembelajaran ialah peserta didik kelas I, perangkat pembelajaran juga dirancang untuk menarik minat baca peserta didik dengan gambar-gambar yang menarik. Hal ini juga bertujuan agar perangkat pembelajaran juga bisa dikerjakan dan dipahami sendiri oleh peserta didik. Hal tersebut relevan dengan pendapat Sudjana (dalam Djamarah dan Zain, 2002), tujuan perangkat pembelajaran ialah untuk melatih peserta didik berpikir mantap dalam kegiatan belajar dan memperbaiki minat belajar peserta didik karena perangkat pembelajaran dibuat lebih sistematis, berwarna, serta bergambar untuk menarik perhatian peserta didik untuk mempelajarai perangkat pembelajaran.

\section{PENUTUP}

Berdasarkan hasil penelitian dan pembahasan, ditarik kesimpulan sebagai berikut.

1. Perangkat pembelajaran BK untuk mengoptimalkan perkembangan sosial anak kelas I SD berada pada kategori layak. Hal ini berarti para ahli sepakat bahwa perangkat pembelajaran yang disusun layak untuk diimplementasikan atau digunakan oleh guru kelas (guru BK/konselor) dalam memberikan layanan kepada siswa.

2. Tingkat keterpakaian Perangkat pembelajaran BK untuk mengoptimalkan perkembangan sosial anak kelas I SD berada pada kategori tinggi. Artinya, bahwa Perangkat pembelajaran BK untuk mengoptimalkan perkembangan sosial anak kelas I SD dapat digunakan sebagai media dalam layanan bimbingan dan konseling.

Produk yang dikembangkan ini berupa modul yang khusus untuk diimplementasikan pada peserta didik kelas I SD.Penggunaan perangkat pembelajaran untuk selain peserta didik SD diperlukan perumusan yang tepat sesuai dengan karakteristik peserta didik tersebut. Perangkat pembelajaran yang dikembangkan hanya sebatas pada uji coba kelompok kecil, untuk itu perlu dilakukan uji coba lapangan untuk melihat efektivitas pemakaian perangkat pembelajaran BK untuk mengoptimalkan perkembangan sosial anak kelas I SD, dan implementasi perangkat pembelajaran ini akan dapat terlaksana dengan baik apabila guru kelas (guru BK/konselor) memiliki kelengkapan alat pendukung dan diharapkan selalu melengkapi dan melakukan perencanaan yang matang sebelum memberikan layanan kepada siswa.

\section{REFERENSI}

Ahmadi, A., dan Sholeh, M. (2005). Psikologi Perkembangan. Jakarta: Rineka Cipta.

Daryanto. (2013). Menyusun Modul Bahan Ajar untuk Persiapan Guru dalam Mengajar. Yogyakarta: Gava Media.

Djmarah, S.B. dan Zain, A. (2002). Strategi Belajar Mengajar. Jakarta: Rineka Cipta.

Hurlock, E. B. (1978). Psikologi Perkembangan Anak. Jilid 1. Jakarta: Erlangga. 
Vinda Chairunnisa, M. Fauzi Hasibuan

Jurnal Bimbingan dan Konseling Ar-Rahman

Volume 4, Nomor 2, Tahun 2018

e-ISSN 2477-6300

Molenda, M. (2003). "In Search of the Elusive ADDIE Models".Jurnal Performance Imnprovement, 42 (3): 34-36

Peraturan Menteri Pendidikan dan Kebudayaan Republik Indonesia Nomor $57 \quad$ Tahun 2014 tentang Kurikulum 2013 Sekolah Dasar/Madrasah Ibtidaiyah. 2014. Jakarta: Depdikbud.

Peraturan Menteri Pendidikan dan Kebudayaan Republik Indonesia Nomor 111 Tahun 2014 tentang Bimbingan dan Konseling pada Pendidikan Dasar dan Pendidkan Menengah. 2014. Jakarta: Depdikbud.

Peraturan Menteri Pendidikan Nasional Nomor 35 tahun 2010, tentang Standar Prosesuntuk Satuan Pendidikan Dasar dan Menengah.2010. Jakarta: Depdiknas.

Prayitno. (2009). Wawasan Profesional Konseling. Padang: UNP.

Tim Penyusun. (2016). Panduan Operasional Penyelenggaraan $B K \quad S D$. Jakarta: Kementerian Pendidikan dan Kebudayaan.

Trianto. (2011). Pengantar Penelitian Pendidikan bagi Pengembangan Profesi Pendidikan dan Tenaga Kependidikan. Jakarta: Kencana Prenada Media Group.

Yusuf, S. LN. (2014). Psikologi Perkembangan Anak dan Remaja. Bandung: Remaja Rosdakarya. 